\title{
Evaluation of Learning Material in the Textbook for Senior High School Grade XI
}

\author{
Zahrina Ulfa ${ }^{1 *}$ and Edi Trisno ${ }^{2}$
}

\author{
${ }^{12}$ English Department, FBS UniversitasNegeri Padang, Padang, Sumatra Barat 25131, Indonesia \\ ${ }^{*}$ Corresponding author. Email: zahrinaulfaa01@gmail.com; edi.trisno@fbs.unp.ac.id
}

\begin{abstract}
Textbook is important in the process of teaching and learning because it is used by the students and teachers in the classroom. It helps students to get information related to the learning especially in learning English. Appropriate textbook is important thing for senior high school during the teaching and learning process to comprehend English learning material clearly. This study was aimed to evaluate the English learning material in the textbook, especially the textbook for senior high school students. The students' textbook used by the SMA students grade XI that produced by Kemendikbud was the source of this study. This study was an evaluation research to evaluate the product in order to describe the existed condition in the field. The evaluatice checklist was used to evaluate English learning material in the textbook. As a result of the study, the evaluation of the textbook related to the English learning material was identified and classified based on Cunningsworth's theory and BNSP Standard. It consisted of the compatibility of the material with Cuningsworth theory and the sufficiency of the material with BNSP Standard.
\end{abstract}

\section{Keywords: Evaluation, Learning Material, Textbook}

\section{INTRODUCTION}

A curriculum consists of objectives, content, and learning materials grouped in plans and arrangements as well as the method used as a guideline for implementing learning activities to achieve certain educational goals [1]. In this case, the curriculum is used to control the teaching and learning process. However, the government has currently developed a new curriculum from KTSP (Kurikulum Tingkat Satuan Pendidikan) to the 2013 Curriculum (Kurikulum 2013). This curriculum is firstly introduced and applied in 2014. It aims to prepare Indonesian people's ability to live as faithful, productive, creative, innovative, effective, and capable individuals and citizens for the life of community, country, and nation, [2].

Based on the Minister of Education and Culture Regulation No. 36/2018, one of the characteristics of the 2013 Curriculum is developing competencies in the form of the group of core competencies further detailed in basic competencies of the subjects. Obviously, two competencies must are achieved by the students called core competencies (Kompetensi Inti/KI) and basic competencies (Kompetensi Dasar/KD). In Senior High School (SHS) or Sekolah Menengah Atas/Madrasah Aliyah (SMA/MA) thecore competency is the level of ability to achieve graduate competency standards (Standar Kompetensi Lulusan/SKL) that the students must have at each grade. The formulations of core competencies are core competency-1 (KI-1) for spiritual affective competence, core competency-2 (KI-2) for social affective competence, core competency-3 (KI-3) for cognitive competence, and core competency-4 (KI4) for psychomotor competence. Meanwhile, basic competencies (Kompetensi Dasar/KD) are formulated to achieve then core competencies. These competencies are developed by considering the students' characteristics and abilities and the particularities of each subject [2].

In addition, the curriculum also provides a learning approach called a scientific approach consisting of observing, questioning, associating, experimenting, creating, and networking [3]. Thus, these steps must contain in the textbooks. Within these steps, teachers can still use the approaches or methods which are relevant or appropriate to the student's level and needs. However, these two competencies and the scientific approach are used to develop syllabus and materials in the textbooks. The textbooks are written based on the curriculum concept: core competencies, basic competencies, and syllabus [2]. Therefore, it is necessary to evaluate textbooks or materials in the textbook for achieving the aim of the 2013 curriculum since textbooks are used by teachers and students in the process of teaching and learning. Clearly, the textbooks or learning materials must be suitable to the core competencies, basic competencies, and syllabus. The 
evaluation of the materials in the textbooks is important to do since it is useful for the teachers' development [4]. It will help them build nice and benficial view into the nature of the materials. Furthermore, by evaluating the materials, the strengths and weaknesses of the textbooks that are used can be identified. Another reason why textbook materials are important to be evaluated is because the textbook is a map. It shows where one is going and where one has been.

Moreover, a textbook is a picture for the educators and learners to know the materials that have been studied and will be studied [5]. Then, it is used as a learning resource containing learning materials, learning practices by students, and vocabulary, pronunciation, grammar, listening, reading, speaking, and writing activities [4].

Deeply, textbooks have been used mostly as a learning media including in language learning, especially English. They are the primary resource sof learning providing English learning materials. They provide a learning direction for teachers and students to know the materials they have studies previously and they will study [6]. Besides, for the teachers, textbooks do not only give the picture to apply the new curriculum but also help them in delivering the learning materials by providing many appropriate examples of practices. In English learning, they are also still mostly used as learning resources although nowadays the Internet has provided materials widely. English textbooks have a variety of roles: introducing written and spoken materials, encouraging interaction, providing references to grammar and vocabulary, acting as a source for classroom activities, offering work that can be accessed by students independently, and providing self-directed learning [4].

Dealing with the textbooks, there are five elements of learning materials intextbooks: title, core competencies or main material, supporting material, exercise, and assessment [7]. These elements must be available to become good textbooks. The materials in the textbook must suitable to the core and basic competencies of the 2013 curriculum. Then, they must have supporting materials such as pictures and conversation for the students that they can implement the material in the real life. Besides, they provide the exercise and the assessment needed in the textbook so that the teachers understand the students' ability.

Based on the explanation above, it can be said that the evaluation of the materials in the textbook are an important process since it is necessary for the teaching and learning process' effectiveness. The teaching and learning process may not run well if the textbooks contain inappropriate materials for students and teachers' needs. This evaluation also can help the organizations the books' publisher in decision making to help teachers in building and choosing textbooks, and to find out the appropriateness of the contents in the textbooks with the students' needs and with the 2013 Curriculum. Moreover, it helps teachers to get suitablecourse books and lets them manage and adjust to meet the students' needs.

Clearly, some studies have been conducted dealing with the textbook and curriculum materials demand. The textbook entitled "When English Rings a Bell" for grade VII of junior high school in Indonesia needs improvement such as providing workbook and audiotapes as supporting aids, adding the rules of structures and vocabulary items, and giving examples and explanations of grammar [8]. In addition, the English textbooks for junior high school grade VII, VIII, and IX are covered in local or Indonesian culture [9].

Furthermore, evaluating the writing materials for the students grade VIII suggests that specific references to vocabulary and grammar materials are required for individual learning. The materials should be more varied and provide the students more to the different context [10]. Nevertheless, speaking materials in the "Pathway to English" textbook is following the syllabus of the 2013 curriculum [11]. Besides, the English textbook used in SMK for students grade XI does not meet the criteria for teacher books since the publisher only provides student books and does not publish teacher books [12]. Slightly different, Indonesian students used the cultural contents on English textbooks. In conclusion, amount of culture of the textbooks were mostly varied in its element and source [9].

Basically, textbooks contains title, core competencies or main materials, supporting materials, exercises, and assessments [7]. These elements must be fulfilled to become good textbooks. The materials in the textbook must suitable to the core and basic competencies of the 2013 curriculum. They must have supporting materials such as pictures and conversation that students can implement in the real life. Besides, the exercise and the assessment are also needed in the textbook so that the teachers understand the students' ability.

Moreover, the senior high school English teachers and students in Padang also use textbooks in the classroom. The textbooks are based on the 2013 curriculum (mostly produced by Kementerian Pendidikan dan Kebudayaan Republik Indonesia. Textbooks must help the teacher to deliver the materials to the students. Unfortunately, in reality based on the result of interview of the English teacher in SMA 3 Padang said, the presence of the textbook may not be sufficient. Therefore, the teachers will not use the textbooks if the textbooks cannot help them in delivering the materials. They argued that sometimes the material in the textbooks is too difficult and too easy for the students. As the result, they just brought the textbook to the classrooms but kept them on their tables.

Furthermore, the textbook did not guide content and material decisions such as what topics to discuss. Otherwise, the textbooks are lack listening activities and $\mathrm{CD}$ (s) for multimedia support. It also did not cover the main grammar items. The materials provided in the textbook are limited to vary contents and materials for different students. For this reason, in using the textbook, 
the teachers used strategies to adapt the textbooks by modifying tasks, adding, and omitting materials.

Teachers and educators should conduct material evaluations since textbooks are designed to meet both of the students and teachers' needs. Some parts of the materials may not meet the students' needs, core and basic competencies, and syllabus although the materials are well-designed and established. In addition, there might still appropriate between the the textbook materials with the curriculum demands. Hence, it is necessary to evaluate the material in the textbook.

Considering the importance of textbooks in the process of teaching and learning, it is interested to evaluate the materials in textbooks for senior high school for the students grade XI produced by Kementerian Pendidikan dan Kebudayaan Republik Indonesia. This research evaluated the compatibility of the materials in the textbook based on the core competencies and basic competencies based on Cunningsworth [4].

Previously, other studies evaluated the materials in textbooks for one semester. However, this study analyzed the materials in the textbook for two semesters entitled "Bahasa Inggris" produced by Kementerian Pendidikan dan Kebudayaan Republik Indonesia revised edition. Besides, there are two inter-raters in this study: the English teachers who have experience and are capable of teaching English and the lecturer in Universitas Negeri Padang. Then, this study was conducted in three schools to find out various perceptions. Although there are many studies on textbook evaluation, the newly published textbooks are paid less attention. Thus, it is the gap of the study that can be filled.

However, the textbook evaluation is expected to give the advantages and disadvantages of the teaching materials. As the result, it can be useful for improving the materials' quality and revising their contents by the syllabus designers, experienced and inexperienced teachers, materials developers, and educational authorities.

\section{METHODS}

Evaluation research was used in this study since it evaluatedlearning material in the textbook for senior high school students grade XI published by Ministry of Education and Culture. Thus, the data were taken from the evaluative checklist of learning material in the textbook titled Bahasa InggrisKelas XI Edisi Revisi 2017 written by the Kementerian Pendidikan dan Kebudayaan Indonesia.

Evaluative score was applied to analyze learning materials from English textbook. For the Cunningsworth's criteria, the score were consisted of very poor, poor, agree, and very agree. While for BNSP standard, the criteria was based on the criteria suggested by Kemendikbud 2013. Then, the discussion and the conclusion were made after getting the data.

\section{RESULTS AND DISCUSSION}

There were two parts of these results. First was the compatibility of the material with Cunningsworth's theory [4]. It consisted of aim and approaches, design and organization, language content, skills, and topics. Second was the sufficiency of the material with BSNP Standard [13]. It consisted of the compatibility of the material with the core and basic competencies, the accuracy of the material, and the supporting material. These results explained the learning material in the textbook for senior high school students grade XI. The following explanation explain each part of these results.

There were the compatibility of the material with Cuningsworth theory. First indicator contains that a textbook should have several requirements: appropriate with the aims in syllabus and curriculum flexible to any teaching and learning situation and style, and appropriate with the students' learning styles

Second indicator contains that a textbook should have attractive illustration. Then, its design help students' language acquisition and development. It help them to learn easily including the grading providing in the textbook.

Third indicator contains that enaugh grammar items should be provided in the texbook so that the students can learn autonomously and the source of grammar knowledge is teacher. Then, the number of the vocabulary in terms must be sufficiently provided in a textbook. Individual sounds, word stress, and intonation must also be provided in the textbook for the teachers.

Fourth indicator contains that the language materials must be integrated based on the skills needed by the students. The materials require enough and rich reading text. Furthermore, the fifth indicator contains that a textbooks must provide the learning materials based on the students' interests. It provides students with something new.

Thus, this study showed that learning materials in the textbook has fulfilled the criteria of the textbook based on each indicator: aim and approach, design and organization, language content, language skills and topic. Unfortunately, the design and organization in the textbook was monotone. It did not catch the students' interesting to learn by using the learning materials in the textbook. Also, several topics in the textbook did not relate to the students' experience (such as in chapter 5 and 6).

Furthermore, there were the sufficiency of the material with BNSP Standard. First indicator, it was the compatibility of material with core competence and basic competence. Textbooks have to contain and require students to examine English texts that give them a chance to comprehend the written and spoken communication including in interpersonal functions based on the situation of the communication taking place.

After that, in depth aspect, it was exposure. For learning each type of text, the textbook have to contain and require students to examine many texts relevant to the students' daily life to familiarize themselves with 
text types, specifically the message fulfillment, party and relevant spiritual skills.

In addition, there were retention of text formation rules, production and extension. For learning each text types, the textbook have to consist guidance so that students comprehend the purpose of the text, parts and meaning structure, and features of the linguistic forms which are the three requirements of text types. Students normally link to the meaning of the texts' content, so it is said that the purpose and the spiritual skills are applicable in these texts.

Second indicator was accuracy of the material. Social function, the texts in the textbooks and the students' study results were directed at achieving the purpose of the texts related to daily life. Then, the generic structures, the texts were given in the textbook and students' exploration were directed at building the think ability meningfully and comprehensively. The last, the features of linguistic forms, the texts given in the textbook and the students' exploration results were directed at buiding the ability to communicate with language quality that is accurate and acceptable, following the ongoing communicative context and text types used to achieve each intended social function.

Third indicator was supporting materials. It related to the up-to-datedness. The relevance of reference material and sources and update material and reference sources. There were teaching materials that are text, tables, pictures, and attachments and learning experiences for each text types were taken from sources relevant to the topics discussed.

In addition, the text and communicative actions encourage students to do some things for life skill development. Then, diversity was text and communicative actions that also encourage students to conduct several things for the heterogeinity attitude development. They were respect for cultural heterogeneity and the plurality of comunity, including many cultural morals and the three parts of wisdom: local, national, and global. Besides, it was geographical wealth awareness and walth to encourage narrow and wide prospective. Furthermore, appreciation of democratic values under the local socio-cultural context. The last, it was understanding the national view to build a love sense for the homeland, nation, and state.

Referring to the results of this study related to the BSNP standard, it can be understood that the textbook has been suitable with the students' learning materials but several chapters did not fulfiil the criteria of the learning materials for grade XI such as compatability, accuracy and supporting. Unfortunately, the textbook still used simple learning materials. It should present the new topic that relate to students' experience and background knowledge.

Regarding to the results above, it is able to classified that the SMA students textbook grade XI produced by Kementerian Pendidikan dan Kebudayaan Republik Indonesia was average textbook. However, this textbook needs revision and evaluates several aspects that make this textbook better. It has to consider to make the learning materials related to the nowadays situation.

\section{CONCLUSION}

From the results above, it can be concluded that there are several conclusion. First, it is need to be decided that the suitable learning materials in the textbooks for senior high school grade XI need some improvements especially in choosing authentic topic that relate with the students' situation and background knowledge. Also, the design and organization can be improved to make the students interest to learn by using the textbook. Second, the compatability and accuracy of the materials have to consider to ease the student in learning. It can be stated that several components need to revise for the future used.

\section{ACKNOWLEDGMENT}

First of all, I really thank Allah SWT who blesses me in writing this paper. I also would like to thank to English Education Study Program, UniveristasNegeri Padang. The warmest appreciation is given to my supervisor Dr. Edi Trisno, M.A.for guiding me with constructive advices to finish this paper. This paper of course needs improvements, but I hope it will give benefits for the development of education especially for other researchers. Moreover, advices and critics from the readers will be much appreciated.

\section{REFERENCES}

[1] "Minister of Education and Culture Regulation No. 20/2003."

[2] "Minister of Education and Culture Regulation No. 36," 2018.

[3] "Display of Deputy Minister of Education and Culture," 2014.

[4] A. Cunningsworth, "Choosing your coursebook." A Division Of Macmillan, Publisher Limited, Thailand, 1995.

[5] Ur, A Course in Language Teaching, Practice and Theory. Cambridge: Cambridge University Press, 1991.

[6] B. Tomlinson, Materials Development in Language Teaching. Cambridge: Cambridge University Press, 1998.

[7] A. Prastowo, Panduan Kreatif Membuat Bahan Ajar Inovatif. Yogyakarta: Diva Press, 2011.

[8] S. Handayani, "The Evaluation of English Textbook for Grade VII of Junior High School in Indonesia," pp. 328-339, 2016.

[9] D. A. Gunantar, "Textbooks Analysis: Analyzing English As A Foreign Language (EFL) Textbooks From The Perspective Of Indonesian Culture," Lang. Circ., vol. 11, no. 2, pp. 173-182, 2017.

[10] M. Lisa, "An Analysis of Writing Material in English Textbook " When English Rings the Bell ' for Eighth Grade,' Retain, vol. 06, no. 01, pp. 78-86, 2018.

[11] Rohmatillah and D. A. Pratama, “An Analysis 
of Textbook Entitled ' Pathway to English ' Published By Erlangga at the First Semester of the 11 th Grade of Senior High School," vol. 10, no. 2, pp. 326-343, 2017.

[12] Margana and Widyantoro, "An Evaluation of English Tectbook Used at Senior and Vocational High Schools Oreinted to the Curriculum 2013," J. Arts, Sci. Commer., vol. VII, no. 4(1), pp. 108-119, 2016.

[13] BSNP, "Instrumen Penilaian Buku Teks Pelajaran," 2014. 